\title{
НЕГАТОРНЫЙ ИСК, КАК СПОСОБ ЗАЩИТЫ ТИТУЛЬНЫХ ПРАВ ВЛАДЕЛЬЦЕВ НЕДВИЖИМОСТИ
}

\section{NEGATORY CLAIM AS A WAY OF PROTECTING THE TITLE RIGHTS OF PROPERTY OWNERS}

\section{A. Seleznyov \\ O. Efimova}

Summary: The article deals with the features of title ownership, violation of title rights and their protection by negator action. The article describes the basis, subject, subject structure, and limitation period of a noncompensatory claim. The application of a negation claim in the protection of title rights of real estate owners is considered on the example of the rights of land owners. The advantages of a non-compensatory claim in protecting the title rights of real estate owners are noted. The article also considers the correlation between a negator claim and a vindication claim, which is also a real-law method of protecting the rights of owners.

Keywords: title ownership, protection of title rights, negation claim, vindication claim, real estate, land plots.
$\Pi$ од титульным владением понимается владение, которое опирается на законное основание, вытекающее из юридического соответствующего факта (напр., право собственности, основанное на договоре купли продажи вещи или переходе ее в порядке наследования). Титульным владельцем следует признавать субъекта, который владеет вещью на основании вещных прав (права собственности и иного ограниченного вещного права) или обязательственных прав [5, с. 53].

Необходимо отметить, что нарушение титульных прав не всегда связано с непосредственной утратой владельцем права фактического владения вещью, которая ему принадлежит на законном основании. Нарушение его прав возможно и путем совершения действий, которые прямо не направлены на препятствование владению, но при этом мешают нормальной реализации иных правомочий собственника: права пользования и распоряжения. В указанных случаях негаторный иск является самым классическим способом защиты имущественных прав, поскольку в ст. 304 Гражданского кодекса Российской Федерации (далее - ГК РФ) закреплено право собственника на устранение всяких нарушений его права, даже если эти нарушения и не были соединены с лишением владения [1].

Современное российское законодательство за последнее время провело несколько реформ в сфере применения негаторного иска. Законодатель предложил по
Селезнев Артем Борисович

НОУ ВО «Российская академия адвокатуры и нотариата»,

2. Москва

selezart@yandex.ru

Ефимова Ольга Владимировна

К.ю.н., дочент, НОУ ВО «Российская академия адвокатуры и нотариата», г. Москва

Аннотация: В статье рассмотрены особенности титульного владения, нарушения титульных прав и их защиты с помощью негаторного иска. Дана характеристика основания, предмета, субъектного состава, срока исковой давности негаторного иска. Применение негаторного иска при защите титульных прав владельцев недвижимости рассмотрено на примере прав владельцев земельных участков. Отмечены преимущества негаторного иска при защите титульных прав владельцев недвижимости. Также рассмотрено соотношение негаторного иска с виндикационным иском, являющимся также вещноправовым способом защиты прав владельцев.

Ключевые слова: титульное владение, защита титульных прав, негаторный иск, виндикационный иск, недвижимость, земельный участки.

аналогии применять данный способ защиты и к правам владельца против самоуправства собственника или третьих лиц в отношении владеющего имуществом на законных основаниях несобственника вещи [2, с.122]. В соответствии со ст. 305 ГК РФ наряду с правом собственности также защите подлежат и права иного титульного владельца [1].

Юридическое основание негаторного иска - это обстоятельства, подтверждающие существование у истца права собственности, ограниченного вещного права или иного субъективного права на вещь, пользование и владение которой затрудняется неправомерными действиями третьего лица. При предъявлении негаторного иска истцу необходимо доказать свой титул на вещь, возможность пользования которой нарушается ответчиком. Негаторное требование требует представления доказательств титульным владельцем своего права, то есть наличия у него гражданского субъективного права. В случае невозможности предоставления истцом данных доказательств судом будет отказакон в удовлетворении иска $[6$, с. 80].

В то же время при негаторном иске ответчик не ставит под сомнение наличие субъективного права у истца на спорную вещь, нарушение проявляется в создании фактических помех в пользовании недвижимой вещью. Исходя из этого суд, исследуя доказательства и оценивая обстоятельства дела, более формально подходит к 
вопросу доказывания титула истца по негаторному иску. В противовес этому ответчик по иску о признании вещного права, как правило и ответчик по виндикационному иску, оспаривает наличие субъективного права истца на предмет спора, тем самым обостряет вопрос о наличии у истца титула на вещь [6, с. 80].

Особо необходимо остановиться на вопросе об определении предмета и субъектного состава негаторного иска. Следует отметить, что негаторный иск содействует устранению препятствий в реализации права собственности, если такие препятствия не связаны с утратой фактического владения самой вещью. Таким образом, негаторный иск имеет неразрывную связь с правом реально существующей собственности при фактическом владении вещи.

Учитывая специфичные особенности содержания негаторного иска, с теоретической точки зрения необходимо выделить два вида правонарушений, которые различаются по характеру незаконного воздействия на вещь:

1. отрицательный тип правонарушения как практическое основание негаторного иска, при котором потерпевший собственник утрачивает возможности реализации каких-либо правомочий пользования и распоряжения;

2. положительный тип правонарушения, исходя из которого объекту вещного права причинен ущерб действиями ответчика, имеющими незаконный характер [3, с. 157].

Отечественное законодательство предоставляет любым титульным владельцам право защиты собственности с помощью негаторного иска, в том числе и от самого собственника, и от всех иных третьих лиц.

Применение негаторного иска при защите титульных прав владельцев недвижимости можно рассмотреть на примере прав владельцев земельных участков. В качестве предмета негаторного иска при защите имущественных прав на земельный участок можно отнести три группы требований материально-правового характера:

1. требования, касающиеся устранения противоправных действий в отношении правомочий владения и (или) пользования, которые связаны с владением частью земельного участка, если собственник земельного участка сохраняет фактическое владение им;

2. требования об исключении нарушения правил соседского права;

3. требования о недопустимости осуществления лицом действий, которые способны в дальнейшем привести к нарушению право собственности, или требования о совершении конкретных действий от третьего лица для предупреждения нарушения права собственности [4, с. 125].
В качестве истца по негаторному иску выступает собственник земельного участка или титульный владелец (арендатор или постоянный землепользователь), а ответчиком является только то лицо, которое своими действия ограничивает истца в реализации своих законных прав, связанных с пользованием или распоряжением земельным участком. Объектом требования по анализируемому иску является прекращение действий, препятствующих осуществлению полноценного права собственности, имеющее длительный характер, и сохранившееся к моменту подачи иска [4, с. 126].

Исходя из этого, на правовые отношения по данному иску не распространяется срок исковой давности, в чем проявляется характерное различие данного иска от виндикационного, срок исковой давности которого составляет три года (п. 4 ст. 302 ГК РФ). Так, в ст. 208 ГК РФ указано, что исковая давность не распространяется требования собственника или иного владельца об устранении всяких нарушений его права, хотя бы эти нарушения не были соединены с лишением владения (ст. 304).

Исковое требование негаторного характера может быть заявлено в любой момент, пока сохраняется факт нарушение права. В качестве одного из условий предъявления негаторного иска выделяется «длящийся характер правонарушения». Исходя из этого, если к моменту направления иска данные действия, имеющие незаконный характер прекратились, утрачивается и основание для его предъявления. В данной ситуации собственник имеет право требовать лишь возмещения причинённых ему убытков или может применить иной способ защиты собственного права.

Помимо этого, негаторный иск используется лишь тогда, когда другие лица своими действиями создают препятствия собственнику для осуществления им прав по распоряжению или пользования имуществом, которое ему принадлежит. Основанием для подачи негаторного иска является доказанный факт истца на имеющееся у него право пользования и распоряжения имуществом, а также обстоятельства, которые подтверждают формирование ответчиком преград для реализации истцом данных правомочий [3, с. 158].

Исходя из этого, право собственности как право абсолютного характера подлежит защите лишь в том случае, если будет непосредственно доказан сам факт его нарушения. Удовлетворение негаторного иска подразумевает конкретное выявление и квалификацию действий ответчика. Данные действия могут быть различными, однако они обязаны непосредственно адресоваться в отношении конкретной вещи, находящийся в фактическом владении собственника. В качестве примера можно привести, посадку деревьев вблизи межевой границы с соседним участком, которые по мере своего 
роста начинают склоняться на соседний участок соседа. Тем самым происходит затемнение соседнего участка и его засорение.

При этом действия ответчика не обязательно должны быть противоправными, потому что основным условием, в данном случае, является само субъективное отношение и реакция на них со стороны управомоченного лица (собственника, титульного владельца). В качестве достаточного основания для направления негаторного иска, в данном случае, нередко является несогласие на прекращение осуществление данных действий самого ответчика [4, с. 127].

Так, например, для одних соседей, близкая посадка деревьев соседом не будет являться препятствием для использования земельного участка, и они будут считать, что это нормальное расположение растений на приусадебном участке. Другие же напротив, посчитают, что такие деревья помешают им в дальнейшем высаживать на своем участке любые растения и соседские деревья будут засорять их участок. Таким образом, при одних и тех же действиях в первом случае нарушения прав нет, а во втором есть. Ввиду этого, можно говорить, что не всегда действия при негаторном иске явля- ются противоправными.

Также стоит обратить внимание на соотношение негаторного и виндикационного иска. Правомочия владения и пользования являются тесно взаимосвязанными между собой и, как правило, не существуют друг без друга, а также при отсутствии четких границ владения и пользования недвижимостью у ряда субъектов этих прав, данные иски по-прежнему будут конкурировать (заявляться истцами и рассматриваться судом с применением ст. 301 либо ст. 304 ГК РФ) между собой при рассмотрении указанных категорий споров, в зависимости от наличия субъективного права, характера правонарушения и «удобства применения» в каждом конкретном случае.

Подводя итог рассмотрения негаторного иска, как способа защиты титульных прав владельцев недвижимости, можно отметить, что юридическое основание негаторного иска представляет собой не только субъективное вещное право (и интерес), на основании которого истец обладает титулом на спорную вещь, но и обстоятельства, обосновывающие права и интерес истца на спорную вещь, в том числе на основании фактической презумпции законности владения.

\section{ЛИТЕРАТУРА}

1. Гражданский кодекс Российской Федерации (часть первая) от 30.11.1994 № 51-Ф3 (ред. от 31.07.2020) // Собрание законодательства РФ. 1994 . № 32. Ст. 3301.

2. Кулинич 0.П. Защита прав собственника земельного участка от нарушений, не связанных с лишением владения, посредством негаторного иска / 0.П. Кулинич // Российский юридический журнал. - 2014. - № 1. - С. 121-127.

3. Курскин П.А. Защита права собственности посредством негаторного иска / П.А. Курскин // Уголовно-исполнительная система России: проблемы и перспективы: материалы международной научной конференции адъюнктов, аспирантов, курсантов и студентов / под общ. ред. Е.А. Тимофеевой. - Самара: Изд-во Самарского юрид. ин-та ФСИН, 2015. - С. 156-159.

4. Макаренко А.А. К вопросу о негаторном иске как способе защиты имущественных прав / А.А. Макаренко, Е.А. Зайцева, А.А. Шумских А.А. // Перспективы развития институтов права и государства: сборник научных трудов 3-й международной научной конференции / отв. ред. А.А. Горохов. -Курск: Изд-во Юго-Западного гос.ударственный университет, 2020. - С. 124-128.

(с Селезнев Артем Борисович (selezart@yandex.ru), Ефимова Ольга Владимировна. Журнал «Современная наука: актуальные проблемы теории и практики» 